\title{
Derivational Processes in Igala Numeral System: Some Universal Considerations
}

\author{
Gideon Sunday Omachonu \\ Nasarawa State University
}

\begin{abstract}
This paper investigates derivational processes in the Igala numeral system to provide a detailed description of the system. The study relies on three major sources in gathering data for the descriptive analysis, namely, compilation of relevant list of Igala numerals, the researcher's intuitive knowledge of the language in addition to his training as a linguist, and a search of the relevant literature. In Igala, the complexity of deriving especially non-basic numerals involves addition and multiplication in addition to the grammatical processes: drawing from phonological, morphological, and syntactic processes such as vowel elision, compounding, clipping, blending, reduplication, and sentential expressions that yield several numeral forms in the language. In all, from the available data in this study, Igala could be said to belong to the group of languages that has a vigesimal numeral system. This is because the language employs a numeral structure where counting is done majorly in multiples of ógwú/ògbò
\end{abstract}

\footnotetext{
Gideon Sunday Omachonu

Department of Languages and Linguistics, Nasarawa State University, Keffi-NIGERIA

Phone: +2348065309796,+2348058421956; Email: gsomachonu@yahoo.com
}

Received May 6, 2011; Revised July 14, 2011; Accepted August 1, 2011. 
'twenty.' In all, this report may not be as exhaustive, but it is hoped that the study has achieved its primary aim of providing a detailed description of the derivational processes in Igala numeral system in addition to helping the reader to appreciate the importance of this kind of research as it relates to typological considerations as well as universality of the grammar of numeracy in languages.

Keywords: igala numerals, vigesimal, derivational processes, arithmetic, grammatical

\section{Introduction}

The Igala language belongs to the West Benue-Congo phylum (formerly part of Kwa) and is one of the 'Yoruboid' languages spoken in North Central Nigeria (Akinkugbe 1976, 1978; Omachonu 2000, 2002). It is a minority language spoken by about two million people who live on the eastern part of Kogi state covering nine (9) Local Government Areas of the state. It is under-documented and scantily described judging from the quantity and quality of documented and analysed/described data in it. Although one may argue that Igala is unlikely to be so endangered in the proper sense of the word considering the number of its native speakers and linguistic researches available in the language (Armstrong 1951, 1965; Omachonu 2000, 2002, 2003a, 2003b, 2006, 2007a, 2007b, 2008; Atadoga 2007; Ejeba 2009; Ikani 2010), one of the aspects always identified as being so seriously endangered in the use and study of the language is the numeral system (See Etu 1999, Ocheja 2001). This is because children nowadays rarely know how to count in Igala. Even adults, mix up Igala with Hausa and English when they count money and other objects in the language. A similar scenario was pointed out by Atóyèbí (n.d.) of the numeral system of Okọ which he described as the most endangered aspect of the language because the act of counting in Okọ, according to him, has 
been left to older members of the community with the younger generation preferring to express numerals in the English language instead.

In the opinion of Comrie $(2005,2006)$, there are many instances of languages that are not particularly endangered, but whose numeral systems are endangered. According to him, language death is the result of social factors and numeral systems or counting generally is particularly susceptible to social factors. He illustrates this further (Comrie 2006: 1):

A community encountering another community with greater numeracy may well borrow the "missing" parts of its system from that other community, but the contact may also involve replacements of parts or all of the existing system, and can also affect languages that come into contact even where there is no great difference in numeracy, but just cultural or commercial superiority of one group over the other.

This, one would agree with Comrie, explains why numeral systems are even more endangered than languages. It has therefore become imperative to document endangered numeral systems before they die out completely. It is to be noted that we are probably where we are today - a situation where so many numeral systems have died out to the point that what remains is only a pale reflection of the "human potential" with respect to numeral systems (Comrie 2006) - due to lack of systematic and careful documentation of the numeral systems of many of our languages. Regrettably, Comrie (2006: 1) concludes that given the present rate of death of languages in the world, "It may well no longer be possible even approximately to determine what the range of possible numeral systems in natural language is or to assess what the relative frequency of different types would be...."

Numeracy is a very important aspect of any linguistic system. 
Counting and or numbering is an integral and inseparable part of the grammar of any language because there is hardly any meaningful linguistic discourse in a language that does not make reference to quantity, size, time, distance, and weight in definite numbers or numerals. As language changes following its dynamic nature, so do its contents, systems, and patterns which counting is a part. Against this background, the aim of this study is to document and provide a detailed description of the Igala numeral system with a view to discussing the derivational processes involved and providing explanations for certain changes that have occurred in the system over time.

It is to be noted that in the presentation of data in this work, I make use of the standard Ígálà orthography (Miachi \& Armstrong 1986) as well as IPA symbols especially where a word is rendered in phonetic transcription. Equally, with respect to tone marks, the acute accent [' ] on a tone-bearing segment, usually a vowel represents a high tone, all instances where any particular vowel is not tone marked represents the mid tone, and the grave accent ['] on any tone-bearing segment represents a low tone.

\section{Counting in Igala}

Here, we shall limit our study of the numerical system of the language to counting from one (Ínyẹ́ [Ínć]/ókà) to a thousand (íchámù nyí ògwọ́kó [ítámùnógwókó]). It appears from all indications that the traditional counting system of Igala did not go beyond the figure one thousand (1000). Besides, for clarity of presentation, we shall equally categorize Igala numerals into two broad groups as far as counting from one to a thousand is concerned. These are the basic numerals and the derivatives (See also Anagbogu 2006). In clear terms, whereas the basics are the primary numerals which are monomorphemic in nature, the derivatives are the secondary or non-basic 
numerals whose derivational history is traceable to a combination of the basic numerals through some addition, multiplication or a combination of both processes. Sometimes, these derivations in Igala numerals involving mathematical manipulations could be very complex and cumbersome hence the proposals for modernization by some researchers on Igala numerals (Etu 1999, Ocheja 2001), which we shall also present/review in the course of this discussion.

\subsection{The Basic Numerals}

In counting from one to a thousand in Igala, the following are considered as the basic numerals because as enunciated earlier above, they are mono-morphemic and they are used for deriving the secondary numerals through some grammatical (phonological, morphological, and syntactic) and or mathematical (addition and multiplication) processes.

(1) a. Basic Numerals 1-10:

\begin{tabular}{|c|c|c|}
\hline ínyẹ́ & [Ínć] or ókà [ókà] & 'one' \\
\hline èjì & [èdzì] & 'two' \\
\hline ẹ̀tā & ['̀tā] & 'three' \\
\hline èlẹ̀ & [غ̀̀)̀ & 'four' \\
\hline è̀lú & [Èlú] & 'five' \\
\hline è̀ẹ̣ & [દ̀fà] & 'six' \\
\hline èbiē & [èbjiē] & 'seven \\
\hline èjọ̄ & [غ่dz?] & 'eight' \\
\hline èlá & [Èlá] & 'nine' \\
\hline ègwá & [غ̇gwá] & 'ten' \\
\hline
\end{tabular}


b. Numerals $20,50,200,400$, and 800 :

\begin{tabular}{|c|c|c|}
\hline ógwú & [ógwú] or ògbọ [j̀gbò] & '20' \\
\hline óójē & [óódzē ] & '50' \\
\hline ògwá & [j̀gwá] & '200' \\
\hline úlú & [úlú] & '400’ \\
\hline íchámù & [ítámù] & ' 800 ' \\
\hline
\end{tabular}

\subsection{The Secondary or Non-Basic Numerals}

As Anagbogu (2006) observed in respect of Koring, membership of this category is potentially uncountable and endless and could run into millions and even billions but what the analyst needs is a deliberate manipulation of the basic figures or numerals to arrive at more complex numerals by derivation and extension. In what follows, we shall present numerals in this group by sub-dividing them into the following sub-sets:

\subsubsection{Numerals Derived by Addition of Two Basic Numerals}

\section{(11-19)}

(2) ègwá \# ókà $\rightarrow$ ègwákà è̀gwá \# èfà $\rightarrow$ ègwẹ́fà

ten one 'eleven' ten six 'sixteen'

ègwá\# èjì $\rightarrow$ ègwéjì è̀gwá\# èbiē $\rightarrow$ ègwébiē

ten two 'twelve' ten seven 'seventeen'

è̀gwá \# ẹ̀tā $\rightarrow$ ègwétā è̀gwá \# è̀jọ $\rightarrow$ è̀gwẹ́jọ̣

ten three 'thirteen' ten eight 'eighteen'

ègwá \# ẹlẹ̀ $\rightarrow$ ègwẹ́lẹ̀ è̀gwá\# ẹ̀lá $\rightarrow$ ègwệlā

ten four 'fourteen' ten nine 'nineteen' 


$$
\begin{array}{ll}
\text { ègwá \# èlú } \rightarrow \text { ẹ̀gwẹ́lū } \\
\text { ten } & \text { five }
\end{array}
$$

As could be observed from the above, the derivation of 11 to 19 takes only the addition of the cardinal basic numerals 1-9 to base ten. The combination of any two basic numerals to derive another numeral, apart from the arithmetic process of addition, equally subscribes to a phonological process of vowel elision whereby the last vowel of the base numeral ten (ègwá) is elided and its tone transferred to the initial vowel of the following cardinal/basic numeral that combines with it except the first example, ègwá \# ókà $\rightarrow$ ègwákà where the first vowel of the second word got elided instead. This is to be expected because even though the emerging central dialect of Igala prefers this form ègwákà, it is realized as ègwókà in Ibaji dialect. And this when carefully analyzed in the light of the derivation of the other examples will attest to the fact that the form ègwókà in Ibaji should have been the basic alternant of the form for numeral eleven in Igala language. Besides, another striking feature of the numerals in this category is that even though the sense addition is expressed, there is no overt addition morpheme to suggest that we add a basic numeral to another basic numeral to derive a secondary or non-basic form. See the forms in 2.2.2 below for derivations involving the use of overt conjunction or addition morpheme as against the examples in 2.2.1 earlier (above).

\subsubsection{Numerals Derived by Addition of Two Basic Numerals} (21-29)
(3) ógwú \# nyí \# òké \# kà $\rightarrow$ ógwúnyíòkékà twenty plus SG.figure ${ }^{1}$ one
'21' [ógwúnókēkà]

\footnotetext{
${ }^{1} \mathrm{SG}$. is used as an abbreviation for singular.
} 


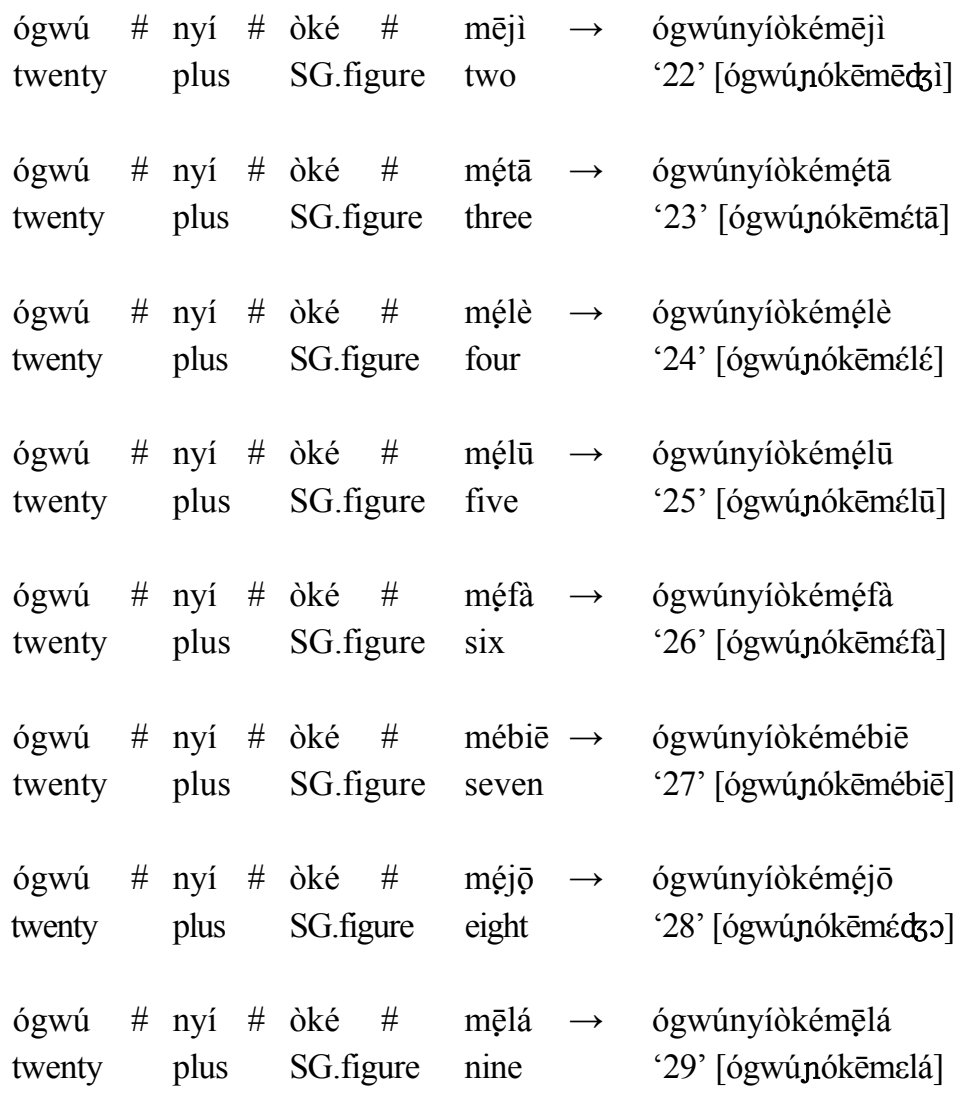

Note that the full form of the word for plus nyi in Igala is manyu/manyi which means 'in addition to.' It means that in deriving these forms, apart from the phonological process of vowel elision, there is also a morphological process of clipping as it affects the word manyu/manyi which gets reduced to -nyi with the first syllable chopped off; likewise the reduction of ókà to kà so as to blend with the other morphemes or words in order to achieve the derivation process involved in arriving at these numerals. In addition, the numerals are actually sentential when rendered in their full forms 
e.g., ógwú \# nyí \# òké \# kà = ógwú ki mányí(ú) ókà = 'Let twenty be added to one.' It is to be noted that some dialects of Igala particularly Ibaji, uses both ówó 'hand' and oké 'single figure' interchangeably for counting in this context as demonstrated in (4) below:

\begin{tabular}{|c|c|c|c|c|c|c|}
\hline $\begin{array}{l}\text { ógwú } \\
\text { twenty }\end{array}$ & \# & $\begin{array}{l}\text { nyí \# } \\
\text { plus }\end{array}$ & $\begin{array}{l}\text { ówọ́ } \\
\text { hand }\end{array}$ & \# & $\begin{array}{l}\text { kà } \\
\text { one }\end{array}$ & $\begin{array}{l}\rightarrow \text { ógwúnyị́́wọ́kà } \\
\text { '21’ [ógwúnókēkà] }\end{array}$ \\
\hline $\begin{array}{l}\text { ógwú } \\
\text { twenty }\end{array}$ & $\#$ & $\begin{array}{l}\text { nyí \# } \\
\text { plus }\end{array}$ & $\begin{array}{l}\text { ówọ́ } \\
\text { hand }\end{array}$ & \# & $\begin{array}{l}\text { mējì } \\
\text { two }\end{array}$ & $\begin{array}{l}\rightarrow \text { ógwúnyị́́wọ́mējì } \\
\text { '22' [ógwúnókēmēdzì] }\end{array}$ \\
\hline $\begin{array}{l}\text { ógwú } \\
\text { twenty }\end{array}$ & $\#$ & $\begin{array}{l}\text { nyí \# } \\
\text { plus }\end{array}$ & $\begin{array}{l}\text { ówọ́ } \\
\text { hand }\end{array}$ & \# & $\begin{array}{l}\text { mẹ́tā } \\
\text { three }\end{array}$ & $\begin{array}{l}\rightarrow \text { ógwúnyị́́wọ́mẹ́tā } \\
\text { '23’ [ógwúnókēmétā] }\end{array}$ \\
\hline $\begin{array}{l}\text { ógwú } \\
\text { twenty }\end{array}$ & \# & $\begin{array}{l}\text { nyí \# } \\
\text { plus }\end{array}$ & $\begin{array}{l}\text { ówọ́ } \\
\text { hand }\end{array}$ & \# & $\begin{array}{l}\text { mẹ́lẹ̀ } \\
\text { four }\end{array}$ & $\begin{array}{l}\rightarrow \text { ógwúnyị́̂wọ́mẹlè } \\
\text { '24’ [ógwúnókēmélè] }\end{array}$ \\
\hline
\end{tabular}

\subsubsection{Numerals Derived by Multiplication in Multiples of Twenty $(40,60,80,100)$}

In the Igala counting system the word ógwú (twenty) is synonymous with $\grave{g} g b \grave{o}$ as pointed out earlier in (1b) above. Therefore as we go into multiplication to derive higher sums, preference is given to the use of $\dot{g} g b \dot{o}$ in multiples of twenty to derive 40,60, and 80, except in 100 where the two forms are used interchangeably. See examples as presented in (5) below:
(5) Ò̀gbò \# mējì
$\rightarrow$
Ọgbọ̀mējì
twenty two (20x2 or twenty in two places)
' 40 '
Ò̀gbò \# mẹ́tā
Òggbòmẹ́tā
twenty three (20x3 or twenty in three places)
' 60 ' 


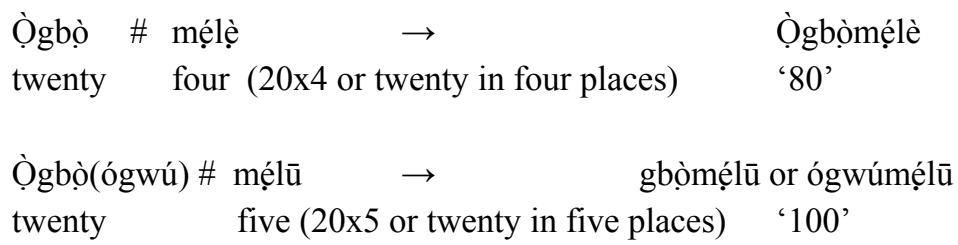

\subsubsection{Numerals Derived by Both Multiplication and Addition of Two Basic Numerals $(30,50,70,90)$}

For these, derivation takes both multiplication and addition except for 30 which takes only addition of two basic numerals. See the data below.

\begin{tabular}{|c|c|c|c|c|c|}
\hline $\begin{array}{l}\text { (6) ógwú } \\
\text { twenty }\end{array}$ & \# & $\begin{array}{l}\text { ègwá } \\
\text { ten }(20+10\end{array}$ & $\overrightarrow{0)}$ & $\begin{array}{l}\text { ógwú-èggwá } \\
\text { '30' }\end{array}$ & [ógwúçgwá] \\
\hline $\begin{array}{l}\text { ẹ̀tā } \\
\text { three }\end{array}$ & \# & $\begin{array}{l}\text { ègwá } \\
\text { ten }(20 \times 3\end{array}$ & $\begin{array}{l}\rightarrow \\
+10)\end{array}$ & $\begin{array}{l}\text { ẹtẹ̀gwá } \\
\text { '70' }\end{array}$ & [ċṫ̀gwá] \\
\hline $\begin{array}{l}\text { èlè } \\
\text { four }\end{array}$ & \# & $\begin{array}{l}\text { ègwá } \\
\text { ten }(20 \times 4\end{array}$ & $\begin{array}{l}\rightarrow \\
+10)\end{array}$ & $\begin{array}{l}\text { èlèggwá } \\
\text { '90' }\end{array}$ & [غ̇lgغ̀wá] \\
\hline
\end{tabular}

One may equally want to know what happens to the numeral fifty (50). It should be noted however that the form for fifty (50) in Igala, óójē [óódzē] has no such derivational history as 30,70, and 90 above. One unique thing about the numeral fifty in Igala is that it appears completely independent. It is neither derived by any other numeral(s) nor does it contribute to deriving other numerals in the language, and hence the proposal at a point in time to use the word óli to represent a unit of fifty in the Igala counting system (Etu 1999). This however did not gain popularity in the system for two reasons: it is only applicable to non-monetary numeration like 
counting heaps and ridges only among the farmers, and secondly, it is only used to designate acceptably 300 (óli mẹ́fà $=50$ in six places) and 500 (óli mégwa $=50$ in ten places) respectively in the Igala traditional numerical system (See also Ocheja 2001).

\section{The Use of Òggwókọ́ (Ò̀gwá), Úlú, Íchámù, and Íchámùnyọwoọ́kó}

Ọ̀gwọ́kọ́ (ògwá), úlú, íchámù, and íchámùnyọ̄gwọ́kó which stand for $200,400,800$, and 1000 respectively were derived or made popular when cowry was used as money in the Igala society. That is why these forms are closely associated with ókọ (money) in their derivations.

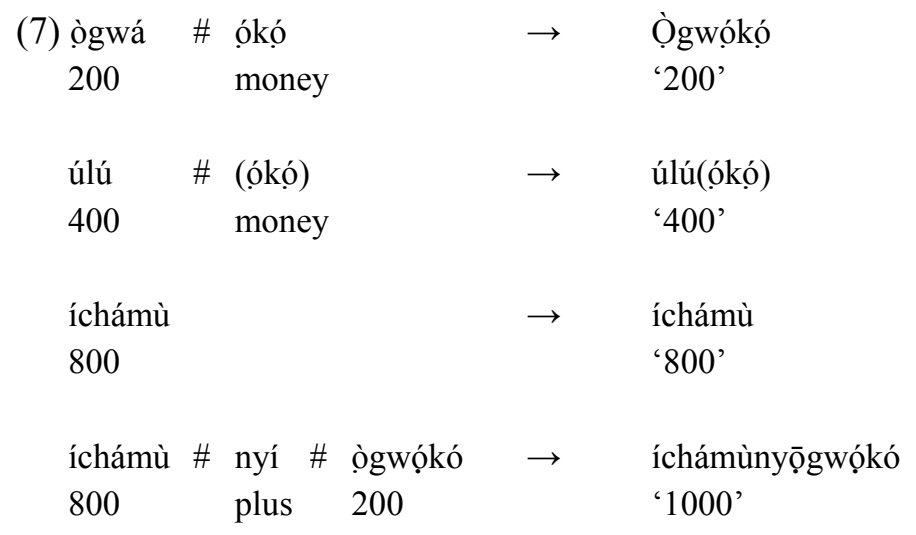

From the data above, it could be observed that the numerals 200, 400 , and 800; in fact 200, 300, 400, 500, 600, 700, 800, and 900 do not refer to the basic numerals 2-9 as the bases for their derivation. So, it becomes very difficult to predict these forms and interpret them, taking a cue from the basic cardinal numerals 1-9 as it is the case with English and other languages. A further investigation even 
reveals that the meanings of these forms: ògwá, úlú, and ichámù are not inherently available in Igala. Again, the word úlu (400) is not as closely associated with money except when cowries were counted in bags and one would hear; úlú àkpúlù, meaning; four hundred bags of money which in the present dispensation - the era of naira, would mean only eighty thousand naira $(\mathrm{N} 80,000)$. In Ibaji dialect where yam farming is a major occupation, the bare forms ògwá and úlú would readily refer to 200 and 400 tubers or seedlings, respectively.

\section{Ordinal Numerals}

The main function of ordinal numerals in Igala numeration is to indentify ranks within a hierarchy with a view to situating a noun referent in a particular hierarchical position. In Igala, as with other languages (See Stolz \& Veselinova 2005, Anagbogu 2006, Atóyèbí n.d.), ordinal numerals are derived from cardinal ones by attaching the prefix -èkó ('you are named or answered') to a cardinal number except first éjódùdu ('morning eye/sight,' lit.) meaning that which the eye sees first in the morning. Here, Igala like Ọkọ (See Atóyèbí, n.d.) can be categorized under languages in which 'first' is suppletive, derivationally independent of the basic numeral 'one' in the language (See also Stolz \& Veselinova 2005). Other numerals from 'two' upwards (ad infinitum) are derived by attaching the prefix -èkó to relevant cardinal numerals (with the required vowel elision).

\begin{tabular}{|c|c|c|c|c|}
\hline (8) ínyẹ́ & [Íné] or ókà [ókà] & 'one' & éjódùdu & 'first' \\
\hline èjì & [èdzì] & 'two' & èkéjì & 'second' \\
\hline ẹ̀tā & {$[\grave{c t a ̄}]$} & 'three' & èkẹ́ta & 'third' \\
\hline ẹ̀lè & [ढ̀lı̀] & 'four' & ẹ̀kẹ́lẹ̀ & 'fourth' \\
\hline èlú & [člú] & 'five' & èkélu & 'fifth' \\
\hline
\end{tabular}




\begin{tabular}{|c|c|c|c|c|}
\hline ẹfà & [Èfà] & 'six' & è̀kẹ́fà & 'sixth' \\
\hline èbiē & [èbjiē] & 'seven' & èkẹ́biē & 'seventh' \\
\hline ẹ̀jọ & [غ̇dz? ] & 'eight' & èkệjộ & 'eightieth' \\
\hline èlá & [člá] & 'nine' & èkẹlá & 'ninth' \\
\hline ẹ̀gwá & [Ėgwá] & 'ten' & èkẹ́gwá & 'tenth' \\
\hline ègwệlū & [غ̇gwélū] & 'fifteen' & èkẹ́gwẹ́lū & 'fifteenth' \\
\hline ógwú & [ógwú] & 'twenty' & èkógwú & 'twentieth' \\
\hline
\end{tabular}

\section{Distributive Numerals}

Distributive numerals in the Igala counting system are derived from cardinal numerals primarily through only total/complete reduplication. This is unlike Anagbogu (2006) and Atóyèbí (n.d.) in Koring and Okọ where deriving the distributive forms is achieved through either partial or completely reduplicated forms of the basic numerals. See the examples of distributive numerals in data (9a-b) below:

(9)

$\begin{array}{llll}\text { ókà } & \text { 'one' } & \text { ókà ókà } & \text { 'one each/one by one' } \\ \text { èjì } & \text { 'two' } & \text { èjì èjì } & \text { 'two-by-two/in twos' } \\ \text { ẹ̀tā } & \text { 'three' } & \text { ẹtā ẹ̀tā } & \text { 'three-by-three/in threes' } \\ \text { ẹ̀lè̀ } & \text { 'four' } & \text { è̀lẹ̀ ẹ̀lẹ̀ } & \text { 'four-by-four' } \\ \text { ẹ̀lú } & \text { 'five' } & \text { ẹ̀lú ẹ̀lú } & \text { 'five-by-five' } \\ \text { ẹ̀à } & \text { 'six' } & \text { è̀fà è̀fà } & \text { 'six-by-six' }\end{array}$

b. ògbọmējì 'forty' ògbọmējì èjì 'forty-by-forty' ògbọmmẹtā 'sixty' ògbọmệtā ẹtā 'sixty-by-sixty' ógwúmẹ́lū 'hundred' ógwúmẹ́lū ẹlú 'hundred-by-hundred'

From the data above, it is clear that the derivation of distributive numerals goes through complete/total reduplications of the basic 
forms. For numeral 1 , even though the form used here is ókà $\rightarrow$ ókà ókà, it does not mean ínyẹ́ cannot be used to derive ínyẹ́ ínyẹ́ as the case may be; it is only that the use of ókà is sometimes preferred in this context due to its melody. It is to be noted also that in (9b) above, though the reduplication appears partial on the surface, it is in the real sense total because the point of emphasis is the figure that is used to effect the multiplication, e.g., èjì èjì, ẹtā ẹtā, and so on whereas ógwú or ògbọ (twenty) as the base is held constant in the derivation. Besides, there is nothing wrong with the forms: ògbọmējì ọgbọ̀mējì, ògbọmẹ́tā ọgbọ̀mẹtā, and ógwúmẹ́lū ógwúmẹ́lū. It is only that for brevity and euphonic melody, preference is, in most cases, given to the forms that reduplicate only the numerals used to multiply the base as presented in (9b) above.

\section{Proposals for Modernization of the Igala Numerals}

Following the difficulties associated with representing certain clumsy numerals in Igala e.g., íchámùnyọ̣gwọ́kó mējì nyí ógwúmẹ́lū mējì nyí ògbọmẹ́lè̀eẹgwá nyí òké mệlá $(2,299)$ as well as those numerals identified with unclear derivational history, certain proposals for modernization were put forward. At present, I would review two of such proposals by Etu (1999) and Ocheja (2001). These two, even though they are not linguists, are native speakers of Igala who have had been associated with the study of Igala language at one point or the other.

Etu (1999) argues that young people especially Igala youths find it difficult to count in their mother tongue because they do not know the counting system of the language. According to him, people find it difficult to learn the unsystematic relationship between numerals 101-2000 because of its clumsy nature. Recall our earlier discussion on the following numerals: ògwọ́kọ (ògwá), úlú, íchámù, and 
íchámùnyọ̄gwọ́kọ as a point at issue here. As against ógwúmẹ́chi for 700 and íchámùnyọgwọ́kọ for 1000, Etu proposed ógwú-mẹ́lū mébiē and ólíu respectively. He argues further to justify the proposal (p. 107): "Óliú is calculated with the concept of óli which is 50 and twenty olis is 1000. Oliu means oli ogwu." He observed however that the word oliu though short and easy to use, is yet to be made popular for acceptability. His conclusion therefore is that, for now, oliu can be used alternately with the more popular íchámùnyọgwọ́kó for 1000 in Igala.

Another voice in this direction as it relates to proposals for modernizing some numerals in the Igala counting system is that of Ocheja (2001). Apart from coining the word ichányi for 1000, the major changes proposed by Ocheja include a departure from the traditional way of counting in multiples of hundreds from 200-1000 to counting in hundreds which translates into the differences between the traditional and the proposed as shown in (10):

\begin{tabular}{|c|c|c|}
\hline (10) OLD & PROPOSED & \\
\hline ọgwọ́kọ́ & ógwú-mẹ́lū mẹjì̀ & ‘200’ \\
\hline ólí-mẹfà & ógwụ́-mẹ́lū mẹ́tā & '300’ \\
\hline úlú (ọ́kó) & ógwụ́-mẹ́lū mẹ́lẹ̀ & ‘400’' \\
\hline ólí-mégwa & ógwụ́-mẹ́lū mẹ́lū & ‘500’ \\
\hline úlú ọgwá & ógwụ́-mẹ́lū mẹ́fà & ‘600’ \\
\hline ógwúmẹ́chi & ógwụ́-mẹ́lū mébiē & ‘700’ \\
\hline íchámù & ógwụ́-mẹ́lū mẹjẹ̄ & ‘ $800 ’$ \\
\hline íchámù nyí ógwú-mẹ́lū & ógwú-mẹ́lū mệlá & ‘900’ \\
\hline íchámùnyọ̄gwọ́kó & íchányì & '1000' \\
\hline
\end{tabular}

The word íchányì, according to Ocheja, is his own derivation of the numeral 1000 from its traditional full form íchámùnyộgwọ́kó taking a cue from the Yoruba egberun (1000) derived from igba marun which literarily means 200 in five places.

One's opinion as far as these proposals are concerned is that it is 
one thing to come up with such elegant proposals but it is another to sell the ideas successfully to the end users. Therefore in issues like this, one may wish to suggest that we should do more of descriptive analysis of the linguistic systems of the language than being prescriptive, know full well that even our insistence can hardly change the situation. Besides, I do not see anything new about some of the proposals except the newly coined terms for 1000. If not, before now, some of us have been used to counting in hundreds from 200 to 1000 (See the appendix on Igala Numerals attached to this paper). However, one may wish to suggest that in dealing with higher figures or numerals such as million, billion, trillion, and so on, the Igala could simply adopt a transliteration of the terms through borrowing to have ímílọinù, íbíliọ̀nù, and so on, respectively.

\section{Summary and Conclusions}

This paper has presented a detailed description of the derivational processes in Igala numeral system with explanations on the derivational history of certain numerals whose meanings are not very obvious in the language as well as certain changes that have occurred in the system over time. The study limits itself to counting from one (Ínyẹ́/ókà) to a thousand (íchámù nyí ọgwọ́kọ́) with the claim that the traditional counting system of Igala did not go beyond the figure one thousand (1000). Besides, for clarity of presentation, Igala numerals were categorized into two broad groups: the basic numerals $(1-10,20,50,200,400$, and 800$)$ and the derivatives or non-basic whose derivational history is traceable to a combination of the basic numerals through some addition, multiplication or a combination of both processes. It has been observed that the form for fifty (50) in Igala, óójē [óódzē ] is somewhat peculiar because it has no such derivational history as 30, 70, and 90 and it appears completely independent as it is neither derived by any other 
numeral(s) nor does it contribute to deriving other numerals in the language.

Even though the orientation of this study is not comparative, a comparison of some of the findings of this study with similar studies would help us to appreciate the importance of this kind of research as it relates to typological considerations as well as universality of the grammar of numeracy in languages. For instance, unlike Yoruba and Ộkọ in which the complexity of deriving especially non-basic numerals involves subtraction in addition to multiplication and addition, in Igala only addition and multiplication are involved in addition to the grammatical processes observed earlier (drawing from phonological, morphological, and syntactic processes that yield several numeral forms). Besides, while in Koring (Anagbogu 2006) the derivation of most secondary numerals involves the use of overt conjunction or addition morpheme (even in deriving numerals 11-19), the derivation of such in Igala does not require the use of such obvious conjunction or addition morpheme. Again, whereas distributive numerals would require either full or partial reduplication in Koring, Yoruba, and Òkọ (See Anagbogu 2006, Comrie 2006, and Atóyèbí n.d. respectively), such derivations in Igala would require only full reduplication.

In all, from the available data in this study, Igala could be said to belong to the group of languages which have a vigesimal numeral system. This is because the language employs a numeral structure where counting is done majorly in multiples of ógwú/ògbọ 'twenty' (Comrie 2005). As indicated from the outset, the primary objective of this study is to contribute to the documentation and description of this most vulnerable aspect of Igala grammar by providing a detailed description of its numeral system. Though this report may not be as exhaustive, it could be said that the study has achieved its primary aim of providing a detailed description of the derivational processes in Igala numeral system. Finally, it is hoped that subsequent or further research into the numeral system of the language will include 
discussions on much more comprehensive descriptive grammar of the Igala numeral system and other related issues including expression of some arithmetic operations such as fractions, addition, subtraction, division, reference to time expressed in hours, days, weeks, months, years, and so on in the numeracy of the language.

\section{References}

Akinkugbe, O. 1976. An Internal Classification of the Yoruboid Group (Yoruba, Itsekiri, Igala). The Journal of West African Languages 11.2, 1-19.

. 1978. A Comparative Phonology of Yoruba (Dialects), Itsekiri and Igala. Ph.D Dissertation. University of Ibadan.

Anagbogu, P. 2006. The Numerical System of Koring: An Analysis. Awaka Journal of Linguistics and Languages 2, 71-75.

Armstrong, R. 1951. A Preliminary Report with Word List. Ibadan: University of Ibadan.

. 1965. Comparative Wordlists of Two Dialects of Yoruba with Igala. Journal of West African Languages 2.2, 51-78.

Atadoga, F. 2007. A Comparative Phonology of Igala and Yoruba. M.A. Thesis. University of Nigeria.

Atóyèbí, J. (n.d.) Oko Numerals and their Derivation. Paper

Presented at the Ph.D Seminar at Max Planck Institute for Evolutionary Anthropology.

Comrie, B. 2005. Numeral Bases. In M. Haspelmath et al. (eds.),

The World Atlas of Language Structures 530-533. Oxford: Oxford University Press.

. 2006. Endangered Numeral Systems. Paper Presented at Max Planck Institute for Evolutionary Anthropology.

Ejeba, S. 2009. A Grammar of Igala Tones. M.A. Thesis. University of Port Harcourt.

Etu, Y. 1999. Igala Expression and Historical Landmarks. Lokoja: 
Enenyo.

Ikani, F. 2010. Phonological Variations in Igala Dialects. M.A. Thesis. University of Nigeria.

Miachi, T. \& R. Armstrong. 1986. Igala Orthography. In R. Armstrong (ed.), Orthographies of Nigerian Languages IV 3251. Lagos: National Language Center.

Ocheja, D. 2001. Modernized Igala Numeral System. Mimeograph. Lokoja: Department of Local Government and Chieftaincy Affairs, Lokoja, Kogi State.

Omachonu, G. 2000. Fundamentals of Phonology and the Study of Igala Language. Ankpa: Bencaz Printing Production.

. 2002. Igala Phonetics and Phonology: An Overview. M.A. Thesis. University of Nigeria.

. 2003a. Animacy Hierachy: A Case for Noun Plural Formation in Igala. In M. Attah et al. (eds.), Language and Literature in Education for a Better Society 201-208. Nsukka: Great AP Express Publishers Limited.

. 2003b. Vowel Sequence and Phonemic Status of the Glottal Fricative in Igala Language. Journal of National Association of Science Humanities and Education Research 1, 223-227.

. 2007a. Syllable Structure and Phonotactic Constraints in Igala. In O. Nedimele (ed.), The Nigerian Festschirift Series for Professor Munzali Jibril $V$ 803-810. Port Harcourt: M\&J Grand Orbit Communication Ltd.

. 2007b. Question Formation in the Igala Language: A Transformational-Descriptive Approach. Journal of the Linguistic Association of Nigeria 10, 191-198.

. 2008. Inflectional Morphology in Igala. Journal of the Linguistic Association of Nigeria 11, 33-40.

Stolz, T. \& L. Veselinova. 2005. Ordinal Numerals. In M. Haspelmath et al. (eds.), The World Atlas of Language Structures. Oxford: Oxford University Press. 


\section{Appendix: Igala Numerals}

\begin{tabular}{|c|c|}
\hline 1. Ínyẹ́ [Ínć] & 30. ógwú-ẹ̀gwá [ógwúġgwá] \\
\hline 2. èjì [èdzì] & 40. ógwú-mējì [ógwúmēdzì] \\
\hline 3. ẹ̀tā [čtā] & [óódłē ] \\
\hline 4. ẹlẹ̀ [člغ̀] & 60. ọggbọ̀mẹ́tā [’̀gb’̀métā] \\
\hline 5. è̀lú [غ̇lú] & 70. ètẹ̀gwá [ċtègwá] \\
\hline 6. èfà [غ̇fà] & 80. ọ̀gbọ̀-mẹ́lẹ̀ [j̀gbòmélè] \\
\hline 7. èbiē [èbjiē] & 90. èlè̀gwá [člc̀gwá] \\
\hline 8. èjjộ [દ̇dzว] & $\begin{array}{l}\text { 100. ógwú-mélū/ọ̀gbọ̀mẹ́lū } \\
\text { [ógwúmélū/ògbòmélū] }\end{array}$ \\
\hline 9. ẹlá [člá] & 200. ógwụ́-mẹ́lū mẹjìiògwá/ọgwọ́kó \\
\hline 10. ẹgwá [Ègwá] & 300. ógwứ-mẹ́lū mẹ́tā [ógwúmélūmétā] \\
\hline 11. ègwákà [غ̇gwákà] & 400. ógwụ́-mẹ́lū mẹ́lẹ̀ [ógwúmćlūmélè] \\
\hline 12. ègwéjì [غ̇gwéḑì] & 500. ógwụ́-mẹ́lū mẹ́lū [ógwúmélūmélū] \\
\hline 13. ègwétā [غ̇gwćtā] & 600. ógwụ́-mẹ́lū mẹ́fà [ógwúmélūméfà] \\
\hline 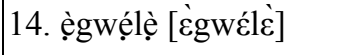 & 700. ógwụ́-mẹ́lū mébiē [ógwúmélūmébiē] \\
\hline 15. ègwẹ́lū [غ̇gwćlū] & 800. ógwụ́-mẹ́lū mẹjjọ̄ [ógwúmélūmédろo] \\
\hline 16. ègwẹ́fà [غ̇gwćlà] & 900. ógwứ-mẹ́lū mẹ̄lá ［ógwúmélūmelá] \\
\hline 17. ègwébiē [غ̇gwébjiē] & $\begin{array}{l}\text { 1000. íchámùnyọ̄gwọ́kọ́ } \\
\text { [ítámùnògwśkś] }\end{array}$ \\
\hline
\end{tabular}




\begin{tabular}{|c|c|}
\hline 18. ègwệjọ̄ [غ̇gwźdろo] & $\begin{array}{l}\text { 2000. íchámùnyọ̄gwọ́kó-mējì } \\
\text { [ítámùnògwókómēdzì] }\end{array}$ \\
\hline 19. ègwẹ́lā [غ̇gwćlā] & $\begin{array}{l}\text { 3000. íchámùnyọggwọ́kó-mẹ́tā } \\
\text { [ítfámùnògwókśmśtā] }\end{array}$ \\
\hline 20. ógwú [ógwú] & $\begin{array}{l}\text { 4000. íchámùnyộgwọ́kó-élè } \\
\text { [ítámùnògwókวmélè] }\end{array}$ \\
\hline $\begin{array}{l}\text { 21. ógwúnyókēkà } \\
\text { [ógwúnókēkà] }\end{array}$ & $\begin{array}{l}\text { 5000. íchámùnyọ̄gwọ́kó-mélū } \\
\text { [ítámùnògwókómélū] }\end{array}$ \\
\hline $\begin{array}{l}\text { 22. ógwúnókēmējì } \\
\text { [ógwúnókēmēèjłi] }\end{array}$ & $\begin{array}{l}\text { 6000. íchámùnyọ̄gwọ́kó-mẹ́fà } \\
\text { [ítámùnògwókśméfà] }\end{array}$ \\
\hline $\begin{array}{l}\text { 23. ógwúnókēmẹ́tā } \\
\text { [ógwúnókēmétā] }\end{array}$ & $\begin{array}{l}\text { 7000. íchámùnyọ̄gwọ́kó-mébiē } \\
\text { [ítámùnògwókśmébiē] }\end{array}$ \\
\hline $\begin{array}{l}\text { 24. ógwúnókēmẹ́lè̀ } \\
\text { [ógwúnókēmélè] }\end{array}$ & $\begin{array}{l}\text { 8000. íchámùnyọ̄gwọ́kó-mẹ́jọ̄ } \\
\text { [ítfámùnògwókóméḑo] }\end{array}$ \\
\hline $\begin{array}{l}\text { 25. ógwúnókēmẹ́lū } \\
\text { [ógwúnókēmélū] }\end{array}$ & $\begin{array}{l}\text { 9000. íchámùnyọ̄gwọ́kó-mẹ̄lá } \\
\text { [ítámùnj̀gwókśmelá] }\end{array}$ \\
\hline $\begin{array}{l}\text { 26. ógwúnókēmẹ́fà } \\
\text { [ógwúnókēméfà] }\end{array}$ & $\begin{array}{l}\text { 1,000,000. íchámùnyọ̄gwọ́kó-mégwa } \\
\text { [ítámùnj̀gwókśmégwa] }\end{array}$ \\
\hline $\begin{array}{l}\text { 27. ógwúnókēmébiē } \\
\text { [ógwúnókēmébiē] }\end{array}$ & 2,000,000. íchámùnyọ̄gwọ́kó-mégwa mējì \\
\hline $\begin{array}{l}\text { 28. ógwúnókēméjōo } \\
\text { [ógwúnókēméḑo] }\end{array}$ & 3,000,000. íchámùnyọ̄gwọ́kó-mégwa mẹ́tā \\
\hline $\begin{array}{l}\text { 29. ógwúnókēmẹ̄lá } \\
\text { [ógwúnókēmelá] }\end{array}$ & 4,000,000. íchámùnyọ̄gwọ́kó-mégwa ẹlè̀ \\
\hline
\end{tabular}

